DOI: https://doi.org/10.24127/ajpm.v8i1.1925

\title{
PENGARUH MODEL PEMBELAJARAN RECIPROCAL TEACHING TERHADAP HASIL BELAJAR MATEMATIKA DITINJAU DARI KEMANDIRIAN BELAJAR
}

\author{
Laila Hidayah $^{1}$, Satrio Wicaksono Sudarman ${ }^{2}$, Ira Vahlia ${ }^{3}$ \\ ${ }^{1,2,3}$ Pendidikan Matematika, Universitas Muhammadiyah Metro \\ E-mail: $\quad$ hidayahlaila19@gmail.com ${ }^{1)}$ \\ rio_sudarman@yahoo.com ${ }^{2)}$ \\ iravahlia768@yahoo.co.id ${ }^{3}$
}

Received 28 Maret 2019; Received in revised form 10 April 2019; Accepted 14 May 2019

\begin{abstract}
The study aims to find out 1) whether or not there is an effect of the Reciprocal Teaching model on students' mathematics learning outcomes. 2) which ones have good mathematical learning outcomes between those who have high, moderate learning independence. 3) interactions between Reciprocal Teaching and conventional learning models. The data analysis technique uses hypothesis testing of twoway anava with unequal cells. Research conclusions: 1) There is an influence of mathematics learning outcomes between those who learn using the Reciprocal Teaching and conventional learning models. 2) Mathematics learning outcomes that have high learning independence are better than those with moderate learning independence and mathematics learning outcomes that have moderate independence are better than those with low learning independence. 3) There is an interaction between Reciprocal Teaching and conventional learning models and learning independence on mathematics learning outcomes in those who have high, medium and low learning independence.
\end{abstract}

Keywords: Learning Independence; Learning Model;Mathematics Learning Outcome; Reciprocal Teaching.

\section{PENDAHULUAN}

Pembelajaran matematika sangatlah penting itu bisa dilihat dari pelajaran matematika sebagai salah satu mata pelajaran yang diberikan di setiap jenjang pendidikan. Pelajaran matematika untuk saat ini masih menjadi masalah bagi sebagian peserta didik. Peserta didik masih banyak yang menganggap matematika sangat sulit, sehingga mereka sering tidak memperhatikan pada proses pembelajaran. Belajar matematika seharusnya dimulai dari urutan yang sederhana menuju pada hal-hal yang lebih kompleks. Suatu konsep dari materi prasyarat yang harus diajarkan lebih dahulu, apabila konsep tersebut akan diperlukan pada pengajaran materi berikutnya. Sampai saat ini matematika masih menjadi masalah bagi sebagian peserta didik yang berakibat pada hasil belajar yang kurang memuaskan. Peserta didik dikatakan berhasil dalam pembelajaran matematika jika mampu mencapai Kriteria Ketuntasan Minimum (KKM) yang ditentukan oleh masingmasing lembaga pendidikan.

Salah satu indikator yang menunjukkan bahwa mutu pendidikan di Indonesia cenderung masih rendah adalah hasil penelitian internasional mengenai prestasi belajar peserta didik. Balitbang (di dalam Haryati, 2015:10) melaporkan hasil survei Trend in International Mathematics and Science Study (TIMMS) pada tahun 2003 indonesia berada diperingkat 34 dari 45 negara. Walaupun rerata skor naik menjadi 411 dibanding 403 pada tahun 1999, kenaikan tersebut secara statistik tidak signifikan dan indonesia masih 
DOI: https://doi.org/10.24127/ajpm.v8i1.1925

berada dibawah rerata untuk wilayah ASEAN. Prestasi belajar pada TIMMS 2007 lebih memperihatinkan lagi, karena rerata skor internasional yaitu 500. Prestasi indonesia pada TIMMS 2007 berada diperingkat 36 dari 49 negara.

Melihat data di atas berarti waktu yang digunakan untuk proses pembelajaran di Indonesia tidak sesuai dengan prestasi yang diraih. Selain melihat hasil belajar matematika peserta didik atau kompetensi pengetahuan, hendaknya pendidik juga memperhatikan kompetensi sikap peserta didik. Hal tersebut sesuai dengan Permendikbud Nomor 66 Tahun 2013 tentang standar penilaian pendidikan bahwa penilaian hasil belajar peserta didik mencakup kompetensi sikap, pengetahuan dan keterampilan.

Pembelajaran matematika tidak hanya semata-mata mencari nilai setelah proses pembelajaran berlangsung akan tetapi peserta didik mampu menerima materi yang diajarkan dan mengaplikasikan dalam kehidupan nyata. Hasil belajar sangat penting dalam dunia pendidikan karena merupakan indikator pencapaian target yang direncanakan. Bagi pendidik hasil belajar tidak hanya menjadi indikator keberhasilan dalam menyampaikan materi kepada peserta didik melainkan penggunaan metode, model atau stategi yang digunakan dalam proses pembelajaran serta menentukan peserta didik yang telah mencapai ketuntasan minimal dan berhak melanjutkan kemateri berikutnya.

Peserta didik masih kesulitan dalam proses pembelajaran matematika. Hal ini diperkuat dengan pernyataan Asri dan Ikhsan (2014), kemampuan belajar matematika peserta didik pada setiap jenjang pendidikan kurang menggembirakan. Prestasi peserta didik dalam matematika umumnya rendah. Lembaga survei PISA (Program For International Student Assessment) menunjukkan rendahnya kemampuan matematika peserta didik Indonesia jika dibandingkan dengan negara-negara lain di dunia. Kenyataan tersebut juga ditemukan di MTs Muhammadiyah Metro kelas VIII tentang hasil belajar matematika peserta didik. Dari hasil wawancara, diperoleh fakta: (1) Peserta didik masih banyak yang belum mencapai KKM yang ada disekolah yaitu 74. (2) Peserta didik belum bisa percaya diri dengan pekerjaannya sendiri masih sering mencontek saat diberikan tugas oleh pendidik di sekolah ataupun pekerjaan rumah. (3) Peserta didik belum mempunyai kemandirian belajar yang tinggi sehingga pendidik harus aktif memerintahkan peserta didik untuk mencari materi yang akan dipelajari atau mengerjakan soal-soal yang ada dibuku paket.

Pernyataan di atas diperkuat dengan data nilai yang diperoleh saat observasi tanggal 13 November 2017 yang dilakukan di MTs muhammadiyah Metro hasil belajar matematika peserta didik dapat dilihat dari nilai mid semester ganjil kelas VIII pada Tabel 1.

Tabel 1. Data Hasil Ulangan MID Semester Peserta Didik

\begin{tabular}{cccc}
\hline No & Nilai & Banyak Siswa & Persentase \\
\hline 1 & $<74$ & 26 & $66,7 \%$ \\
2 & $\geq 74$ & 13 & $33,3 \%$ \\
\hline \multicolumn{2}{c}{ Jumlah } & 39 & $100 \%$ \\
\hline
\end{tabular}


Berdasarkan data pada Tabel 1, terlihat bahwa jumlah peserta didik yang tuntas dalam belajar jauh lebih sedikit dari peserta didik yang tidak tuntas dalam belajar Hal tersebut disebabkan oleh banyak faktor seperti sikap terhadap belajar, motivasi belajar, konsentrasi belajar, rasa percaya diri dan kemandirian belajar. Suid \& Syafrina (2017) menyimpulkan bahwa sikap kemandirian peserta didik dapat dikembangkan oleh guru dengan meningkatkan semua aspek sikap kemandirian, khususnya pada sikap bertanggung jawab dan mengambil keputusan.

Pendidik mata pelajaran matematika menyatakan bahwa kebanyakan peserta didik kelas VIII MTs Muhammadiyah Metro kesulitan memahami materi pada pokok bahasan statistika, karena belum memahami dalam menganalisis data yang berbentuk tabel dan diagram, ukuran pemusatan data yang terdiri dari mean, median dan modus serta ukuran penyebaran data seperti: jangkauan, kuartil, jangkauan antarkuartil dan simpangan kuartil. Kurangya rasa kemandirian belajar dari peserta didik saat disekolah mempengaruhi saat proses pembelajaran berlangsung, masih ditemui peserta didik yang ketika proses pembelajaran kurang percaya diri dengan kemampuan dirinya sendiri seperti saat diberi tugas disekolah atau pekerjaan rumah peserta didik saling mencontek satu sama lain. Sejalan dengan Kulsum \& Djoko (2017) Kemandirian belajar berpengaruh terhadap hasil belajar peserta didik. Proses pembelajaran tersebut disimpulkan bahwa kurangnya kemandirian belajar peserta didik saat proses pembelajaran dan maupun diluar proses pembelajaran, sedangkan kemandirian belajar peserta didik sangat mempengaruhi hasil belajar matematika peserta didik, kemandirian belajar yang tinggi membentuk semangat peserta didik untuk belajar sehingga peserta didik mempunyai hasrat untuk bisa menyelesaikan permasalahan dan mendapatkan hasil belajar matematika yang memuaskan.

Menurut Egok \& Sukenda (2016) kemandirian ialah keadaan dimana seseorang memiliki hasrat bersaing untuk maju demi kebaikan dirinya, mampu mengambil keputusan dan inisiatif untuk mengatasi masalah yang dihadapi, memiliki kepercayaan diri dalam mengerjakan tugas-tugasnya dan bertanggung jawab terhadap apa yang dilakukannya. Ketika penggunaan model pembelajaran yang kurang menarik, sebagian peserta didik merasa jenuh dan kurang aktif dalam proses pembelajaran. Supaya peserta didik lebih mandiri dan semangat belajar, perlu dikembangkan model pembelajaran yang tepat untuk menyampaikan berbagai materi dalam pembelajaran yang memberikan kesempatan bagi peserta didik untuk bertukar pendapat, bekerjasama dengan teman, berinteraksi dengan pendidik dan merespon pemikiran peserta didik yang lain.

Banyak sekali strategi, metode dan model pembelajaran untuk meningkatkan hasil belajar matematika peserta didik. Salah satu model pembelajaran itu adalah dengan pembelajaran Reciprocal Teaching. Hal ini sejalan dengan Ahmad \& Syaiful (2017) model Reciprocal Teaching dapat meningkatkan keaktifan peserta didik sehingga meningkatkan hasil belajar peserta didik. Herman \& Irwan (2014) menyimpulkan bahwa tes hasil belajar pada model Reciprocal Teaching lebih baik daripada pembelajaran konvensional. Siswa diarahkan terlebih dahulu untuk merangkum buku bacaan, sehingga siswa mulai memahami 
DOI: https://doi.org/10.24127/ajpm.v8i1.1925

konsep dari suatu materi pelajaran. Penggunaan model Reciprocal Teaching ini dipilih karena peserta didik banyak dituntut untuk membaca, sehingga dapat menambah pemahaman materi yang telah dibacanya dan memberi kesempatan teman yang mendengarkannya untuk lebih memahami materi, supaya peserta didik lebih percaya diri dan mudah saat berdiskusi dengan temannya. Kebaruan penelitian ini dengan sebelumnya yaitu dalam suatu kelas pasti pasti memiliki kemandirian yang berbeda-beda, ada yang tinggi sedang dan rendah. Kebanyakan penelitian hanya menganggap kemandirian belajar peserta didik hanya tinggi dan rendah. Berdasarkan hasil penelitian Muslimin \& Indaryanti (2017) menyimpulkan bahwa pembelajaran matematika dengan model Reciprocal Teaching adalah tinggi dengan nilai rata-rata 85,26 daripada pembelajaran konvensional. Mulyono (2017) menyatakan bahwa terdapat perbedaan hasil belajar peserta didik dengan pembelajaran timbal balik yang memiliki kemandirian rendah dan kemandirian tinggi, pembelajaran timbal balik dapat meningkatkan kemandirian peserta didik. Hal ini berarti bahwa pembelajaran matematika dengan model Reciprocal Teaching dapat melatih kecakapan akademik peserta didik dan mampu menciptakan hasil belajar yang baik.

Tujuan dalam penelitian ini adalah: (1) Untuk mengetahui ada tidaknya pengaruh model Reciprocal Teaching terhadap hasil belajar matematika peserta didik. (2) Untuk mengetahui manakah yang memiliki hasil belajar matematika yang baik antara peserta didik yang mempunyai kemandirian belajar tinggi, sedang atau rendah. (3) Untuk mengetahui ada tidaknya interaksi antara model pembelajaran Reciprocal Teaching dan kemandirian belajar terhadap hasil belajar matematika peserta didik.

\section{METODE PENELITIAN}

Penelitian ini dilaksanakan di MTs Muhammadiyah Metro pada semester genap tahun pelajaran 2017/2018. Jenis penelitian ini adalah penelitian eksperimen semu, yaitu dengan memberi dua perlakuan berbeda terhadap dua kelompok siswa. Kelompok pertama di berikan model pembelajaran dengan model Reciprocal Teaching sebagai kelas eksperimen, sedangkan kelompok kedua diberikan model pembelajaran konvensional sebagai kelas kontrol. Rancangan penelitian yang digunakan dalam penelitian ini adalah rancangan faktorial $2 \times 3$, maka bentuk Tabel 2 design factorial sebagai berikut:

Tabel 2. Rancangan Design Factorial 2x3

\begin{tabular}{cccc}
\hline \multirow{2}{*}{ Model Pembelajaran $\left(\mathbf{A}_{\mathbf{i}}\right)$} & \multicolumn{3}{c}{ Kemandirian belajar $\left(\mathbf{B}_{\mathbf{j}}\right)$} \\
\cline { 2 - 4 } & Tinggi $\left(\mathbf{b}_{\mathbf{1}}\right)$ & Sedang $\left(\mathbf{b}_{\mathbf{2}}\right)$ & Rendah $\left(\mathbf{b}_{\mathbf{3}}\right)$ \\
\hline Model Reciprocal Teaching $\left(\mathrm{a}_{1}\right)$ & $a_{1} b_{1}$ & $a_{1} b_{2}$ & $a_{1} b_{3}$ \\
Pembelajaran konvensional $\left(\mathrm{a}_{2}\right)$ & $a_{2} b_{1}$ & $a_{2} b_{2}$ & $a_{2} b_{3}$ \\
\hline
\end{tabular}


DOI: https://doi.org/10.24127/ajpm.v8i1.1925

Populasi dalam penelitian ini adalah peserta didik MTs Kelas VIII semester genap tahun pelajaran 2017/2018. Penelitian ini menggunakan teknik cluster random sampling sehingga terpilih sampel sebagai kelas eksperimen yaitu kelas VIII A sebanyak 21 peserta didik dan kelas kontrol yaitu kelas VIII B sebanyak 20 peserta didik. Penelitian dilakukan sebanyak enam kali pertemuan, dimana lima kali pertemuan untuk kegiatan pembelajaran dan satu kali pertemuan untuk tes.

Metode pengumpulan data penelitian meliputi metode tes dan angket. Metode tes digunakan untuk memperoleh data hasil belajar matematika peserta didik. Menurut Sudarman dan Vahlia (2016) untuk mendapatkan data yang akurat, maka soal tes yang akan digunakan perlu di uji validitas dan di uji coba instrumen untuk mengetahui reliabilitas dari soal tes tersebut. Metode angket digunakan untuk memperoleh data kemandirian belajar peserta didik. Sebelum melakukan penelitian, dilakukan uji keseimbangan terhadap hasil belajar menggunakan uji-T. Data hasil belajar matematika dianalisis menggunakan analisis variansi dua jalan dengan sel tak sama. Sebelumnya, pada data hasil belajar dilakukan uji prasyarat meliputi uji normalitas populasi menggunakan metode Lilliefors dan uji homogenitas variansi populasi menggunakan metode Bartlett. Uji hipotesis menggunakan analisis variansi dua jalan dengan sel tak sama. Apabila hasil analisis variansi menunjukkan bahwa hipotesis nol ditolak, dilakukan uji komparasi ganda menggunakan metode Scheffe. Budiyono, (2013:13)

\section{HASIL PENELITIAN DAN PEMBAHASAN}

Berdasarkan penelitian yang telah dilakukan di kelas eksperimen dengan menggunakan model pembelajaran Reciprocal Teaching dan kelas kontrol menggunakan model pembelajaran konvensional pada materi statistika diperoleh data hasil belajar matematika peserta didik yang dapat dilihat pada Tabel 3.

Data hasil belajar matematika peserta didik pada kelas eksperimen lebih tinggi daripada kelas kontrol. Rangkuman hasil perhitungan analisis variansi dua jalan dengan sel tak sama disajikan dalam Tabel 4.

Tabel 3. Data Hasil Belajar Matematika Peserta Didik

\begin{tabular}{ccccc}
\hline Kelas & Jumlah & Nilai Tertinggi & $\begin{array}{c}\text { Nilai } \\
\text { Terendah }\end{array}$ & Nilai Rata-rata \\
\hline Eksperimen & 21 & 95 & 60 & 78,57 \\
Kontrol & 20 & 90 & 60 & 73,25 \\
\hline
\end{tabular}


DOI: https://doi.org/10.24127/ajpm.v8i1.1925

Tabel 4. Rangkuman Hasil Uji Analisis Variansi Dua Jalan Sel Tak Sama

\begin{tabular}{cc|c|c|c|cc}
\hline Sumber & JK & Dk & RK & $\mathbf{F}_{\text {hit }}$ & $\mathbf{F}_{\text {tab }}$ & Kep. Uji \\
\hline Kelas(A) & 220,4 & 1 & 220,4 & 5,7 & 4,121 & $\mathrm{H}_{0}$ ditolak \\
Kemandirian belajar(B) & 2103,1 & 2 & 1051,5 & 27,3 & 3,267 & $\mathrm{H}_{0}$ ditolak \\
Kelas*K.B(AB) & 384,5 & 2 & 192,2 & 4,9 & 3,267 & $\mathrm{H}_{0}$ ditolak \\
Galat (G) & 1347 & 35 & 38,4 & - & - & \\
Total & 4055,2 & 40 & - & - & - & \\
\hline
\end{tabular}

Berdasarkan Tabel 4, $\mathrm{H}_{0 \mathrm{~A}}$ ditolak berarti terdapat perbedaan hasil belajar matematika antara peserta didik yang belajar dengan menggunakan model pembelajaran Reciprocal Teaching dan model konvensional. Hipotesis $\mathrm{H}_{0 \mathrm{~B}}$ ditolak berarti kategori kemandirian belajar tinggi, sedang dan rendah memberikan efek yang berbeda terhadap kemampuan hasil belajar matematika peserta didik.
Uji Komparasi Ganda dengan Metode Scheffe yaitu $\mathrm{H}_{0 \mathrm{~A}}$ ditolak, berarti terdapat perbedaan efek model pembelajaran terhadap hasil belajar peserta didik. Untuk mengetahui mana yang lebih baik antara model pembelajaran Reciprocal Teaching dengan pembelajaran konvensional, maka perlu dilihat rataan marginal hasil belajar peserta didik yaitu pada Tabel 5 .

Tabel 5. Data Rataan Marginal Hasil Belajar Peserta didik

\begin{tabular}{ccccc}
\hline \multirow{2}{*}{$\begin{array}{c}\text { Sumber } \\
\text { Variansi }\end{array}$} & \multicolumn{3}{c}{ Kemandirian Belajar } & \multirow{2}{*}{$\begin{array}{c}\text { Rerata } \\
\text { marginal }\end{array}$} \\
\cline { 2 - 4 } & Tinggi & Sedang & Rendah & \\
\hline Eksperimen & 88,57 & 85,00 & 67,22 & 80,26 \\
Kontrol & 85,00 & 71,67 & 69,50 & 75,39 \\
Rerata marginal & 86,79 & 78,33 & 68,36 & \\
\hline
\end{tabular}

Berdasarkan rataan marginal dari data diatas, tampak bahwa kelas eksperimen memiliki rataan marginal yang lebih besar dari kelas kontrol. Artinya bahwa model pembelajaran Reciprocal Teaching menghasilkan hasil belajar peserta didik yang lebih tinggi dibandingkan dengan pembelajaran konvensional. Pada efek tingkat kemandirian belajar $\mathrm{H}_{0 \mathrm{~B}}$ ditolak, berarti terdapat perbedaan efek kemandirian belajarpeserta didik terhadap hasil belajar matematika, maka perlu dilakukan uji komparasi antar kolom. Berikut adalah rekapitulasi hasil uji Schefee pada kemandirian belajar peserta didik disajikan pada Tabel 6.

Tabel 6. Rangkuman Hasil Uji Komparasi Antar Kolom

\begin{tabular}{cc|cc}
\hline Komparasi & F hit & F kritik & Keputusan uji \\
\hline$\mu_{1}$ vs $\mu_{2}$ & 10,209 & 8,169 & $\mathrm{H}_{01}$ ditolak \\
$\mu_{1}$ vs $\mu_{3}$ & 61,445 & 8,169 & $\mathrm{H}_{02}$ ditolak \\
$\mu_{2}$ vs $\mu_{3}$ & 28,000 & 8,169 & $\mathrm{H}_{03}$ ditolak \\
\hline
\end{tabular}


DOI: https://doi.org/10.24127/ajpm.v8i1.1925

Berdasarkan Tabel 6, dapat disimpulkan bahwa : (1) Pada tingkat kemandirian tinggi memiliki hasil belajar yang tinggi dibandingkan dengan hasil belajar peserta didik yang memiliki kemandirian belajar sedang dan rendah. (2) Pada tingkat kemandirian sedang, menghasilkan hasil belajar yang tinggi dibandingkan dengan hasil belajar peserta didik yang memiliki kemandirian belajar rendah.
Pada efek interaksi antara kemandirian belajar dan model pembelajaran terhadap hasil belajar, menunjukkan adanya interaksi antara model pembelajaran dan kemandirian belajar, maka perlu dilakukan uji komparasi antar sel pada baris (model pembelajaran) yang sama atau pada kolom (kemandirian belajar) yang sama. Rekapitulasi hasil uji komparasi pada Tabel 7.

Tabel 7. Rerata antar sel pada kolom (kemandirian belajar) yang sama

\begin{tabular}{cc|cc}
\hline Komparasi & F hit & F kritik & Keputusan uji \\
\hline$\mu_{11}$ vs $\mu_{21}$ & 0,844 & 12,247 & Ho Diterima \\
$\mu_{12}$ vs $\mu_{22}$ & 12,597 & 12,247 & Ho Ditolak \\
$\mu_{13}$ vs $\mu_{23}$ & 0,639 & 12,247 & Ho Diterima \\
\hline
\end{tabular}

Berdasarkan hasil perhitungan pada Tabel 7 dapat disimpulkan bahwa pada kategori kemandirian belajar peserta didik tinggi, hasil belajar peserta didik pada kelas eksperimen sama tingginya dengan hasil belajar peserta didik pada kelas kontrol. Pada kategori kemandirian belajar sedang, hasil belajar peserta didik pada kelas eksperimen lebih tinggi dari pada hasil belajar peserta didik pada kelas kontrol. Pada kategori kemandirian rendah hasil belajar kelas kontrol lebih tinggi daripada hasil belajar pada kelas eksperimen.

Berdasarkan analisis data hasil belajar matematika diperoleh hasil penelitian yang sesuai dengan uji analisis variansi dua arah diperoleh $F_{\text {obs }}=16,2944$ dan $F=$ 3,1001 maka dapat disimpulkan bahwa $F_{o b s}>F$ artinya ada perbedaan ratarata hasil belajar matematika ditinjau dari kemandirian belajar dengan menggunakan Model Pembelajaran Reciprocal Teaching dan Model Konvensional. Selanjutnya dilakukan uji lanjut dengan metode scheffe maka diperoleh hasil sebagai berikut:
Terdapat pengaruh pembelajaran Reciprocal Teaching terhadap hasil belajar matematika peserta didik. Berdasarkan hasil analisis variansi dua jalan dengan sel tak sama, dengan taraf signifikansi $5 \%$ diperoleh $\mathrm{F}_{\text {hitung }}>\mathrm{F}_{\text {tabel }}$ yaitu $5,727>4,121$ sehingga dapat disimpulkan bahwa ada perbedaan efek antar model pembelajaran pada hasil belajar matematika dengan materi statistika kelas VIII MTs. Muhammadiyah Metro. Rerata Marginal pada penggunaan model Reciprocal Teaching sebesar 80,26 sedangkan pembelajaran matematika dengan pembelajaran konvensional menghasilkan rerata 75,39 maka dapat dikatakan bahwa hipotesis yang diajukan diterima yang menunjukkan bahwa peserta didik yang pembelajarannya menggunakan Reciprocal Teaching memiliki hasil belajar yang lebih tinggi dibandingkan konvensional.

Peserta didik mendapatkan suasana pembelajaran yang berbeda, sehingga peserta didik tidak bosan dan jenuh dengan pembelajaran matematika. Fakta di lapangan juga menunjukkan bahwa kegiatan pembelajaran 
DOI: https://doi.org/10.24127/ajpm.v8i1.1925

Reciprocal Teaching sudah berjalan dengan baik. Peserta didik lebih mandiri dalam belajar, proses diskusi dan tanya jawab berlangsung dengan lancar. Di dalam proses diskusi itulah terjadi proses saling tukar informasi dan pengetahuan antara peserta didik dengan peserta didik maupun peserta didik dengan pendidik. Hal ini membuat peserta didik semakin mandiri dalam belajar.

Terdapat Pengaruh Kemandirian Belajar Terhadap Hasil Belajar Peserta Didik. Berdasarkan hasil analisis variansi dua jalan dengan sel tak sama dengan mengambil taraf signifikansi sebesar 5\% diperoleh $\mathrm{F}_{\text {hitung }}>\mathrm{F}_{\text {tabel }}$ yaitu $27,322>3,267$ sehingga dapat disimpulkan bahwa terdapat pengaruh hasil belajar antara peserta didik kemandirian belajar tinggi, sedang dan rendah. Berdasarkan hasil uji komparasi antar kolom, dapat disimpulkan bahwa peserta didik dengan kemandirian belajar tinggi mampunyai perbedaan rerata dengan peserta didik dengan kemandirian belajar sedang dan rendah. Artinya hasil belajar matematika tertinggi dicapai oleh peserta didik yang memiliki kemandirian belajar yang tinggi. Sesuai dengan hasil penelitian Rohaeti (2013) menunjukkan bahwa setelah mengikuti pembelajaran, kemandirian belajar peserta didik juga meningkat. Peserta didik menunjukkan tanggapan positif terhadap pembelajaran. Peserta didik antusias mengikuti pelajaran. Kemudian peserta didik yang memiliki kemandirian belajar sedang memiliki hasil belajar yang tinggi dibandingkan dengan hasil belajar peserta didik yang memiliki kemandirian belajar rendah. Hal ini berarti kemandirian belajar dengan hasil belajar peserta didik memiliki kekonsistensian yang tinggi.

Berdasarkan hal di atas bahwa kemandirian belajar yang berbeda akan berpengaruh terhadap pencapaian hasil belajar peserta didik. Kemandirian berkaitan erat dengan prinsip kesiapan peserta didik dalam belajar. Peserta didik yang memiliki kemandirian belajar yang tinggi memiliki kecenderungan untuk mempersiapkan diri dalam belajar, baik kesiapan fisik maupun kesiapan mental. Kemandirian peserta didik dalam belajar yang dialkukan peserta didik yaitu mempersiapkan materi-materi pembelajaran yang akan dipelajari pada pertemuan selanjutnya. Dengan mempersiapkan diri dan materi pembelajaran maka peserta didik akan semakin mudah dalam mengikuti kegiatan belajar di kelas. Hal ini karena peserta didik sudah memiliki bekal pengetahuan didalam dirinya sehingga ketika pendidik memberikan pertanyaan kepada peserta didik, peserta didik sudah memiliki kesiapan untuk menjawab pertanyaan.

Terdapat interaksi antara pengaruh pembelajaran dan kemandirian belajar terhadap hasil belajar matematika peserta didik. Berdasarkan hasil uji anava dua jalan sel tak sama dengan taraf signifikansi 5\% diperoleh $\mathrm{F}_{\text {hitung }}>$ $F_{\text {tabel }}$ yaitu 4,955 $>3,267$ sehingga menyebabkan $\mathrm{H}_{O A B}$ ditolak berarti ada interaksi antara model pembelajaran dan kemandirian belajar peserta didik terhadap hasil belajar peserta didik MTs Muhammadiyah Metro kelas VIII pada materi statistika. Hal ini berarti bahwa kemandirian belajar yang disertai dengan efek pembelajaran yang diterapkan pendidik berpengaruh terhadap hasil belajar peserta didik. Pada masing-masing pembelajaran dan kemandirian belajar memberikan efek yang berbeda dalam menentukan hasil belajar peserta didik.

Pada peserta didik yang mempunyai kemandirian belajar tinggi, hasil belajar matematika yang 
mengunakan pembelajaran Reciprocal Teaching sama baiknya dengan hasil belajar matematika yang menggunakan pembelajaran konvensional. Hasil analisis menggunakan uji Schefee menunjukkan bahwa $F_{\text {hitung }}<\mathrm{F}_{\text {tabel }}$ yaitu $0,834<12,247$ sehingga menyebabkan $\mathrm{H}_{0}$ diterima maka kemandirian belajar peserta didik yang tinggi jika diterapkan dengan model pembelajaran Reciprocal Teaching maupun konvensional menghasilkan hasil belajar yang sama tinggi. Fakta di lapangan menunjukkan bahwa peserta didik yang memiliki kemandirian belajar yang tinggi mempunyai rasa percaya diri, tanggung jawab, inisiatif, dan memiliki motivasi yang tinggi dalam belajar. Hal ini ditunjukkan pada hasil angket serta melalui dokumentasi bahwa peserta didik yang mempunyai kemandirian belajar yang tinggi dalam pembelajaran Reciprocal Teaching mampu membuat pertanyaan dan memberikan jawaban yang sesuai dan tepat dalam diskusi. Menurut Pilten (2016) Reciprocal Teaching dapat meningkatkan aktivitas diskusi pada peserta didik. Sependapat dengan Vahlia dan Sudarman (2015) Didalam model pembelajaran berbalik (Reciprocal Teaching) dapat mengeksplorasi kemampuan peserta didik dan menekankan adanya aktivitas serta interaksi diantara peserta didik untuk saling memotivasi dan membantu dalam menguasai materi pelajaran guna mencapai hasil belajar yang maksimal. Sedangkan pada pembelajaran konvensional peserta didik yang mempunyai kemandirian belajar yang tinggi memiliki kesiapan untuk menyelesaikan soal-soal yang diberikan oleh guru.

Hasil analisis menggunakan uji Scheffe menunjukkan bahwa $\mathrm{F}_{\text {hitung }}>$ $F_{\text {tabel }}$ yaitu 12,597>12,247 sehingga menyebabkan $\mathrm{H}_{0}$ ditolak maka kesimpulannya kemandirian belajar peserta didik yang sedang jika diterapkan dengan model pembelajaran Reciprocal Teaching menghasilkan hasil belajar lebih tinggi dibandingkan dengan pembelajaran konvensional. Fakta di lapangan menunjukkan bahwa dalam pembelajaran Reciprocal Teaching dibuat kelompok peserta didik secara heterogen yang terdiri dari peserta didik dengan kemandirian belajar sedang, rendah, dan tinggi sehingga hal ini mampu membuat peserta didik yang memiliki kemandirian sedang dapat meningkatkan aktivitas belajarnya dan mempersiapkan diri dalam kegiatan belajar. Pada peserta didik yang mempunyai kemandirian belajar rendah, hasil belajar matematika yang menggunakan pembelajaran Konvensional lebih baik daripada hasil belajar yang menggunakan pembelajaran Reciprocal Teaching.

Hasil analisis menggunakan $U j i$ Scheffe menunjukkan bahwa $\mathrm{F}_{\text {hitung }}<$ $F_{\text {tabel }}$ yaitu $0,639<12,247$ sehingga menyebabkan $\mathrm{H}_{0}$ diterima maka kesimpulannya kemandirian belajar peserta didik yang rendah diterapkan dengan model pembelajaran konvensional menghasilkan hasil belajar yang sama dengan model pembelajaran Reciprocal Teaching. Fakta di lapangan menunjukkan bahwa dalam pembelajaran konvensional peserta didik yang memiliki kemandirian belajar rendah belum atau bahkan tidak memiliki kesiapan belajar, sehingga hal ini membutuhkan pendidik sebagai penyampai pesan atau materi pelajaran kepada peserta didik.

Pendidik menjelaskan materi pembelajaran secara detail dilengkapi dengan contoh-contoh soal yang bervariasi dan latihan-latihan soal yang lebih intensif. Pada pembelajaran Reciprocal Teaching menekankan pada diskusi kelompok dan menuntut 
DOI: https://doi.org/10.24127/ajpm.v8i1.1925

kemandirian belajar yang lebih baik dibandingkan pada pembelajaran konvensional. Peserta didik yang memiliki kemandirian belajar yang rendah kurang mampu menyesuaikan dengan peserta didik yang memiliki kemandirian belajar yang tinggi dan sedang dalam proses diskusi kelompok. Hal ini karena pada proses diskusi kelompok terlihat hanya peserta didik yang kemandirian belajarnya tinggi mendominasi pada kegiatan diskusi.

Dengan demikian dapat disimpulkan bahwa pada peserta didik yang mempunyai kemandirian belajar rendah dan diterapkan dengan pembelajaran konvensional hasil belajarnya lebih tinggi dari pada peserta didik yang pembelajarannya menggunakan pembelajaran Reciprocal Teaching. Hal ini terdapat perbedaan dengan hasil penelitian Aji (2017) Hasil penelitian menunjukkan bahwa setelah mengikuti pembelajaran dengan pendekatan reciprocal teaching, 100\% peserta didik telah mencapai nilai sesuai dengan Kriteria Ketuntasan Minimal (KKM) secara individual maupun klasikal. Kemandirian belajar siswa dikategorikan baik.

\section{KESIMPULAN DAN SARAN}

Berdasarkan hasil penelitian yang telah dilakukan, maka dapat diambil kesimpulan: pertama, terdapat pengaruh model Reciprocal Teaching terhadap hasil belajar matematika peserta didik. Kedua, Pada peserta didik yang mempunyai kemandirian belajar tinggi, hasil belajar matematika yang mengunakan pembelajaran Reciprocal Teaching sama baiknya dengan hasil belajar matematika yang menggunakan pembelajaran konvensional. Pada peserta didik yang mempunyai kemandirian belajar sedang, hasil belajar matematika yang mengunakan pembelajaran Reciprocal Teaching lebih baik dari hasil belajar matematika yang menggunakan pembelajaran konvensional. Sedangkan pada peserta didik yang mempunyai kemandirian belajar rendah, hasil belajar matematika yang menggunakan pembelajaran konvensional lebih baik daripada hasil belajar yang menggunakan pembelajaran Reciprocal Teaching. Ketiga, ada interaksi antara model pembelajaran dan kemandirian belajar peserta didik terhadap hasil belajar peserta didik

Saran dalam penelitian ini adalah memilih model pembelajaran Reciprocal Teaching pada materi statistika kelas VIII untuk mengoptimalkan hasil belajar peserta didik pada kemandirian belajar yang sedang karena dalam prosesnya peserta didik lebih antusias dalam mengikuti kegiatan pembelajaran. Sedangkan pada peserta didik yang mempunyai rata-rata kemandirian belajar pada kategori rendah pendididik sebaiknya memilih model pembelajaran konvensional, karena dalam konteks ini peserta didik masih memerlukan penjelasan materi pelajaran secara detail dan rinci agar peserta didik dapat memahami materi pelajaran tersebut.

\section{DAFTAR PUSTAKA}

Ahmad, Z. \& Syaiful. (2017). The Effect Of Reciprocal Teaching Strategy Toward Students' Motivation And Their Reading Ability At Senior High School In Rambah Hilir District Rokan Hulu Regency. Journal of English Education, 3(2), 62-72.

Aji, S. P. (2017). Upaya Meningkatkan Prestasi Dan Karakter
Kemandirian Belajar $\begin{array}{r}\text { Siswa } \\ \text { Melalui Pendekatan Reciprocal }\end{array}$ 
DOI: https://doi.org/10.24127/ajpm.v8i1.1925

Teaching Pada Mata Diklat Simulasi Digital. Jurnal Edukasi Elektro, 1(1), 49-56.

Asri, K \& Ikhsan, M. (2014). Meningkatkan Kemampuan Pemecahan Masalah dan Komunikasi Matematis Melalui Penerapan Pembelajaran Kooperatif Tipe Jigsaw pada Sekolah Menengah Atas. Jurnal Didaktik Matematik, 1(2), 85-97.

Budiyono. (2013). Statistika Untuk Penelitian. Surakarta: UNS Press.

Egok \& Sukenda, A. (2016). Kemampuan Berpikir Kritis Dan Kemandirian Belajar Dengan Hasil Belajar Matematika. Jurnal Pendidikan Dasar, 7(2), 185-198.

Haryati, F. (2015). Meningkatkan Kemandirian Belajar Siswa Melalui pembelajaran Dengan Pendekatan Metakognitif Berbasis Soft Skill. Suska Jurnal of Mathematies Education, 1(1), 918.

Herman, A. N \& Irwan, Z. A. (2014). Penerapan Model Reciprocal Teaching Pada Pembelajaran Matematika Siswa Kelas VIII SMP Negeri 26 Padang. Jurnal Pendidikan Matematika, 3(1), 1317.

Kulsum, U. \& Djoko. (2017). Improvement of Learning Independence and Learning Outcomes on Textile Course through Hybrid Learning Model. IOSR Journal Of Humanities And Social Science (IOSR-JHSS), 22(8), 1-5.

Mulyono, D. (2017). The Influence Of Learning Model And Learning Independence On Mathematics Learning Outcomes By Controlling Students' Early Ability. International Electronic Journal of Mathematics Education, 12(3), 689-708.
Muslimin \& Indaryanti. (2017). Pembelajaran Matematika Dengan Model Reciprocal Teaching Untuk Melatih Kecakapan Akademik Siswa Kelas VIII SMP. Jurnal Pendidikan Matematika, 11(1), 1-13.

Pilten, G. (2016). The Evaluation of Effectiveness of Reciprocal Teaching Strategies on Comprehension of Expository Texts. Journal of Education and Training Studies, 4(10), 232-247.

Rohaeti, E. (2013). Peningkatan Prestasi Dan Kemandirian Belajar Mahasiswa Melalui Pendekatan Reciprocal Teaching Dan Cooperative Learning. Jurnal Ilmiah Pendidikan, 1(1), 116-124.

Sudarman, S. W. \& Vahlia, I. (2016). Efektifitas Penggunaan Metode Pembelajaran Quantum Learning terhadap Kemampuan Pemahaman Konsep Matematis Mahasiswa. Jurnal Al-Jabar, 7(2), 275-282.

Suid \& Syafrina, A. (2017). Analisis Kemandirian Siswa Dalam Proses Pembelajaran Di Kelas III SD Negeri 1 Banda Aceh. Jurnal Pesona Dasar, 1(5), 70-81.

Vahlia, I \& Sudarman, S. W. (2015). Penerapan Model Pembelajaran Berbalik (Reciprocal Teaching) Ditinjau Dari Aktivitas Dan Hasil Belajar Siswa. Jurnal Aksioma, 4(1), 59-66. 